\section{Higher Education Systems and Institutions, Costa Rica}

Eugenia Gallardo-Allen

University of Costa Rica, San Pedro, Costa Rica

Costa Rica was a marginal and sparsely populated province of the Spanish Empire during the colonial period (1580-1821). Those interested in pursuing higher education were therefore forced to travel abroad, especially to Nicaragua or Guatemala, where those who chose to pursue nonclerical studies could degree in Medicine and Law, which facilitated the development of an intelligentsia with liberal ideas (González 2006).

The Casa de Enseñanza de Santo Tomás was founded in 1814, at the initiative and with the funding of the residents of the City of San José. This institution of religious orientation, focused on primary and secondary levels, would 29 years later become the Universidad de Santo Tomás, the first higher education institution in the country (Molina 2016).

This university, which maintained its religious and exclusive character for men, is credited with fundamental contributions to the consolidation of the Republic, whose declaration was made in 1885. Apart from the University, there were so-called Normal Schools, dedicated to the training of primary teachers from 1838 onwards.

Considering that its existence weakened the resources allocated to primary and secondary education, the University of Santo Tomás was closed in 1888 as part of the education reforms of the liberal government. Despite this, some faculties such as Law, Pharmacy, and Agronomy continued to function independently (Ruiz 2000).

The Universidad de Costa Rica (UCR) whose educational model is based on the Córdoba Reform was created more than 50 years later, in 1940. This Reform seeks a humanistic university, of a social nature, with a democratic government with student participation, and with full autonomy in the exercise of its functions (González 2006).

The period between 1940 and 1972 is marked by profound political changes that affect Costa Rican education: the civil war and the subsequent abolition of the army in 1948, which makes it possible to increase the economic resources for education and health; the Constitutional Reform, where the principles and responsibilities of the State with the educational system are established; the second University Congress, where the structure of the University of Costa Rica is consolidated as regards to its social and humanistic role. Finally, the General Law of Education was enacted in 1957, establishing the Costa Rican State Educational System as a process articulated from preschool to higher education.

In the 1970s, a process of expansion and massification of higher education began. Three public institutions were created: in 1972 the Technological Institute of Costa Rica (ITCR), in 1973 the National University (UNA), 
in 1977 the State Distance University (UNED). The Autonomous University of Central America (UACA), the first private university in the country, was also founded in 1976. As of this moment, there is an accelerated growth in the number of higher education establishments, reaching 29 parauniversitaria institutions, 54 private universities, 5 public universities (a new public university is created in 2008, the National Technical University, UTN), 5 international universities (which offer 1302 programs in various areas of knowledge) in 2016. Added to these institutions, it is necessary to acknowledge the presence of large transnational educational consortia, such as Laureate and Ilimno, that acquire some domestic private institutions, and the opening of a Texas Tech University campus (Programa Estado de la Educación 2017).

According to the QS-world ranking, the UCR is the most valued university in Central America (position 500-510 in the world and number 19 in Latin America), while the UNA is second in the region (751-800 in the world and 48 in Latin America), while the best-ranking private university is ULACIT (QS Quacquarelli Symonds Limited 1994-2018).

Higher education coverage for 2016 was $51.4 \%$ in the population from 18 to 22 years of age, corresponding to a total of 217,841 students/ people, $55 \%$ of whom were women. $48.6 \%$ were enrolled in private universities and $47.8 \%$ in public universities, while $2.9 \%$ are enrolled in parauniversitaria institutions, and $0.6 \%$ to international universities (CONARE A).

Most public universities establish academic entrance exams as part of their admission process. For example, the UCR, the first to establish these types of requirements. In general, private institutions have open admission policies, only in a few programs do specific tests exist, such as in health programs.

According to the Nomenclature of Degrees and titles of Higher Education (1974), there is distinction between short undergraduate studies (diploma and teaching degrees), full undergraduate studies (bachelor and licenciatura degrees), and postgraduate studies (professional specialization, master's degree, and academic doctorate).
While universities are authorized to award any type of the degrees, the parauniversitaria institutions award only diploma and teaching degrees. In 1976, it was agreed that the unified definition a credit would equal 3 full hours of academic work lasting 15 weeks and supervised by a teacher. This was done so as to facilitate the recognition of studies, qualifications, and degrees.

In 2016, 46,195 titles were awarded both at undergraduate and graduate levels, $69 \%$ of which were issued by private institutions. At a postgraduate level, 3584 master's degrees (69\% of private universities) and 140 doctoral degrees (74\% of private universities) were awarded (CONARE B).

Research production is concentrated in public universities, whose investment in this area is equivalent to $0.18 \%$ of the GDP in 2015 . In the same year, 2200 research projects were developed, and 422 articles indexed published, according to the Web Science database (CONARE C; Programa Estado de la Educación 2017).

The funding of public education is provided by the State. According to Article 78 of the Political Constitution, at least $8 \%$ of GDP must be allocated for all levels of education, from preschool to university. Public university education is financed mainly through the Fund for Higher Education (FEES), which is established every 5 years through a negotiation process between the government and public universities. In 2010, the government and state universities set a goal for public universities to reach $1.5 \%$ of GDP; however, this goal has not been met to date, although in nominal terms funding has increased steadily. In 2010, the FEES represented $1.2 \%$ of GDP and in 2015 , to $1.4 \%$. In terms of total spending on Education, said fund represented $16.5 \%$ in 2010 and $18.9 \%$ in 2015 (Programa Estado de la Educación 2017). Conversely, private universities do not receive funds from the state, although there is a control and a regulatory framework by the state.

The current political constitution (1949) sets out the principle of university autonomy, the freedom of chair, the endowment of resources and the patrimony on the part of the State for state 
education. There are two coordinating bodies of higher education: National Council of Rectors (Conare) created in 1974 and made up of the rectors of the public universities. Among its main functions is the creation, closure, and approval of study programs proposed by public universities. Private universities are coordinated by the Council of Private Higher Education (Conesup), an instance attached to the Ministry of Public Education, which was created in 1981 by law of the Republic. The Conesup has five members, the minister of education (chair) and the others appoints by the following institutions: CONARE, Private Universities, Professional Associations, and National Planning Office. Conesup is responsible for approving the creation of private universities and the approval of their study programs. In addition, private universities have the Unit of Rectors of Private Universities (Unire), whose purpose is articulation and institutional negotiation, although not all private universities are affiliated to this instance.

Under the initiative of the public universities and four private universities, the National System of Accreditation of Higher Education (Sinaes) was established in 1999. Its purpose is to establish quality requirements to improve the programs offered by both public and private institutions and to provide a public guarantee of quality of education. By 2018, the Sinaes reached programs in 26 public and private universities, 5 parauniversitaria institutions, and accredited 166 programs (SINAES).

\section{Trends in Costa Rica's Higher Education}

In terms of public opinion, education has been, and continues to be, a relevant aspect of Costa Rican society. During the 2012-2016 period, eight surveys were conducted on the assessment that Costa Ricans have of various institutions, among which are the Judiciary, the Catholic Church, Political Parties, Social Security, and the Office of the Obudsman. The institution with the best assessment in all the studies was the University of Costa Rica, followed by other public universities, while the private universities were in sixth place (CIEP-UCR).

As of 1998, private universities award a greater number of degrees than public ones, with both sectors having very similar enrollment levels, and therefore there is a concern about the graduation time in the public sector (Gallardo et al. 2012). Additionally, new actors have inserted themselves, such as international consortiums that have acquired domestic higher education institutions, and the presence of international universities.

This panorama increases the concern for the quality of higher education, which has led to efforts to strengthen the evaluation and accreditation mechanisms through the SINAES; however, the voluntary nature of these mechanisms has led to a limited scope of coverage.

Given the limited amount of funding for public universities by the State, there has been a trend in recent years to resort to investment by international organizations such as the World Bank, which provided a loan of 200 million dollars to be executed by public universities in the 2013-2017 period. This loan aims to cover infrastructure needs and strengthen policies aimed at increasing access to higher education.

In this vein, public universities have developed programs and affirmative policies with the purpose of improving access for the local indigenous population and people with special abilities, including differential income requirements, socioeconomic assistance, and academic support (Mainieri 2017).

\section{References}

CIEP-UCR. Informes de encuestas de Opinión 2012-2016. https://ciep.ucr.ac.cr/index.php/proyectos/encuestasde-opinion (consultado 1 de setiembre del 2018).

CONARE A. Estadísticas de la Educación TerciariaUnesco 2011-2017. https://www.conare.ac.cr/ servicios/estadistica (consultado 1 de setiembre 2018).

CONARE B. Miniestadísticas Diplomas. https://www. conare.ac.cr/servicios/estadística (consultado 1 de setiembre 2018).

CONARE C. Indicadores de Investigación 2012-2016. https://www.conare.ac.cr/servicios/estadística (consultado 1 de setiembre 2018). 
Gallardo Eugenia, Molina Mauricio and Cordero Rebeca. 2012. Aplicación de análisis de sobrevivencia al estudio del tiempo requerido para graduarse en educación superior: el caso de la Universidad de Costa Rica. Páginas de Educación. 9 (1): 61-87, Montevideo, jun. 2016. Disponible en http://www. scielo.edu.uy/scielo.php?script $=$ sci_arttext\&pid $=$ S1688-74682016000100003\&lng =es\&nrm =iso > (consultado el 10 setiembre 2018).

González, Yamileth. 2006. Educación y Universidad. San José: Universidad de Costa Rica.

Mainieri, Aida María. 2017. Innovaciones en modelos de admisión: Estudios de casos y estrategias de inclusión educación superior. Revista Actualidades Investigativas En Educación. 17 (3): 64-105. https:// doi.org/10.15517/aie.v17i3.30215 (consultado el 10 de setiembre 2018).
Molina, Iván. 2016. La educación en Costa Rica de la época colonial al presente. San José: Editoriales universidades públicas.

Programa Estado de la Nación. 2017. Sexto Informe Estado de la Educación. https://www.estadonacion.or. cr/educacion2017/assets/ee6-informe-completo.pdf (consultado 1 de setiembre 2018).

QS Quacquarelli Symonds Limited 1994 - 2018. Qs world university rankings. https:/www.topuniversities.com/ universities/level/undergrad/region/latin-america (consultado 1 de setiembre 2018).

Ruiz, Ángel. 2000. La Educación Superior en Costa Rica: Tendencias y retos en un escenario histórico. San José: Universidad de Costa Rica.

SINAES. Información General página Web. https://www. sinaes.ac.cr (consultado 1 de setiembre del 2018). 